\title{
Nano-scale Characterization of Ultra-thin Dielectrics/Conductive Films through Scanning Capacitance Microscopy Studies
}

\author{
Yuichi NAITOU*1 and Heiji WATANABE*2 \\ ${ }^{* 1}$ Nanoelectronics Research Institute, National Institute of Advanced Industrial Science and Technology (AIST), \\ 1-1-1 Umezono, Tsukuba, Ibaraki 305-8568, Japan \\ ${ }^{* 2}$ Graduate School of Engineering, Osaka University, 1-1 Yamadaoka, Suita, Osaka 565-0871, Japan
}

(Received June 11, 2010, Accepted August 2, 2010)

\begin{abstract}
Scanning capacitance microscopy (SCM) techniques to investigate the local electronic properties of the ultra-thin films are presented. In the first part, we show the application of SCM experiments for the high-permittivity (high- $k$ ) dielectric thin films. The static capacitance $(\mathrm{dC} / \mathrm{dZ})$ images and spatially resolved $\mathrm{dC} / \mathrm{dZ}$ versus sample bias spectra have revealed the charge distributions within high- $k$ dielectrics. Moreover, the bias stress examination has clearly imaged the charge-trapped region in the high- $k$ stacked dielectrics. In the second part, we have demonstrated that the conductance variation ascribed to the graphene thickness can be probed through SCM measurements. The UHF field transmitted from SCM probe tip induces a local accumulation of carriers just beneath the tip. This causes carrier diffusion over the effective biased area of $S_{\text {eff }}$ on graphene films, which can be detected as the increment of $\mathrm{dC} /$ $\mathrm{dZ}$ signal intensity. These results indicate that our SCM technique provides a valuable method to explore the electronic characteristics of low-dimensional materials with nanoscale resolution.
\end{abstract}

\section{1. はじめに}

情報処理機器の高速化や低消費電力化は, LSI の基本要素 デバイスである金属-酸化膜-半導体電界効果型トランジスタ (MOSFET) の微細化により実現してきた. しかし主要構成 材料である $\mathrm{Si}$ や $\mathrm{SiO}_{2}$ の物性的な制約から，これまでのよう な MOSFETの等比縮小化, いわゆるスケーリング則はデバ イス世代を追う毎にその難易度を高めている。 そこで現在, MOSFET 開発において特に注力されているテーマが， Fig. 1 に示す(1)ソース・ドレイン電極, (2)ゲート絶縁膜, そして (3)高移動度チャネル材料であり，その各々についてデバイ ス/プロセス研究を支援する目的で, 走査型プローブ顕微鏡 (Scanning Probe Microscopy; SPM) 技術を応用した非常に 多くの観察技術が提案されている.

まず(1)に関わる半導体デバイス評価技術は, 非常に盛んな 研究が行なわれている. ソース・ドレイン電極端の $p-n$ 接 合など MOSFET 内部のキャリア分布を直接可視化する観察 技術があれば，デバイス研究には勿論，プロセス不良解析な どを通じて量産技術にも大いに貢献すると期待される。 SPM 技術を用いた $p-n$ 接合評価については, 既に様々な報 告がなされており, 中には走査型トンネル電流顕微鏡 (Scanning Tunneling Microscopy; STM) を用いて, $p-n$ 接 合近傍で個々のドーパント原子の分布位置を観察した報告例 もある11. STM を用いたこの手法は観察技術として空間分 解能や感度の面でほぼ極められているといってよく, 今後は test-elementary-group（TEG）など試作デバイスの設計手 法と組み合せた応用が期待される。一方，不良解析などでは

*1 産業技術総合研究所エレクトロニクス研究部門（テ305-8568 茨城県つくば市梅園 1-1-1)

*2 大阪大学大学院工学研究科 (干565-0871 大阪府吹田市山田丘 2-1)

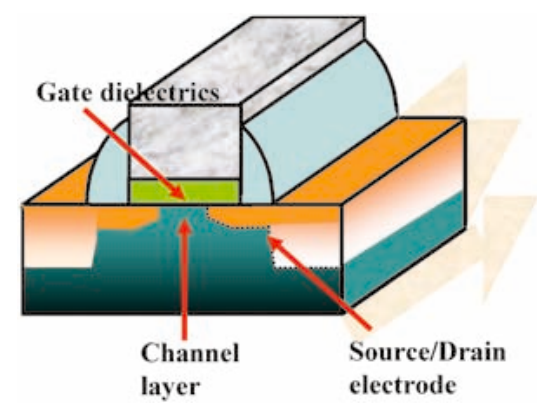

Fig. 1 Schematic structure of MOSFET and experimental target of SCM measurements.

実デバイスにより近い構造の試料を観察するために, STM にくらべてより簡便な測定技術も望まれており, それらの候 補としては走査型広がり抵抗顕微鏡 (Scanning Spreading Resistance Microscopy; SSRM $)^{2)}$ や走查型容量顕微鏡 (Scanning Capacitance Microscopy; SCM) などが挙げられ る.さらに近年では，このSCM を用いた上記(2)及び(3)への 応用に関する論文発表が増えつつある. 本稿では, 薄膜材料 を対象とした SCM の測定手法について主に紹介する.

ここで(2)の背景について説明すると，スケーリング則によ り $2 \mathrm{~nm}$ 以下まで極薄膜化した $\mathrm{SiO}_{2}$ ゲート絶縁膜を流れる リーク電流は, デバイスの消費電力や信頼性に深刻な影響を 与えるため, $\mathrm{SiO}_{2}$ を置き換える高誘電率 $($ high $-k)$ 材料と して $\mathrm{Hf}$ 酸化物 $\left(\mathrm{HfO}_{2}\right)$ などの金属酸化物の導入が求められ ている. high- $k$ 材料では, 従来の $\mathrm{SiO}_{2}$ や $\mathrm{SiON}$ よりも高い 誘電率の材料をゲート絶縁膜として用いることで, 物理膜厚 を厚く保ったまま極薄膜 $\mathrm{SiO}_{2}$ を用いた場合と同等以上のデ バイス特性が期待される. 既に一部のメーカーにおいて最先 端 LSI への high- $k$ 材料導入は報告されている33 が，しかし その特有の物性について必ずしも十分に理解されているわけ 
ではない。例えば, high- $k$ 材候補のひとつである $\mathrm{HfO}_{2}$ はイ オン性物質であり，共有結合物質である $\mathrm{SiO}_{2}$ に比べると， 膜中に多くの欠陥が存在する．これらの欠陥は膜中固定電荷 や電荷トラップとして働き, ゲート絶縁膜として用いた場合 にしきい值電圧のシフト・トラップ媒介のリーク電流・チャ ネル内キャリアの移動度低下など MOSFET の顕著な特性劣 化を招きかねない. 従って, デバイス特性の信頼性確保や, また更なる薄膜化などの特性改善を実現するためには, high- $k$ 材料の微視的物性に関する知見が必須となる. 後述 するように, SCM では局所的な容量一電圧 (CapacitanceVoltage; $\mathrm{C}-\mathrm{V})$ 特性を見ることができるので, 半導体基板 上の誘電体膜中に存在する電荷トラップなどの観察には相性 の良い測定法といえる.

また(3)の背景について述べると, ワイヤレスデバイスへの 応用など MOSFET の高周波スイッチング特性を向上するた めに, Si にくらべてより高移動度のチャネル材料の導入が 期待されている。このため, $\mathrm{SiGe} / \mathrm{Ge}$ ，あるいは $\mathrm{GaAs}$ など の異種半導体を $\mathrm{Si}$ ベースの LSI へ組み込む研究が集中的に 行なわれている.さらにその発展として, 単原子層グラファ イトであるグラフェンやカーボンナノチューブ (Carbon Nano Tube; CNT) などのナノカーボン材料を, MOSFET のチャネルとして利用する提案もある. 特にグラファイトは 室温で Si をはるかに超える〜 $2 \times 10^{6} \mathrm{~cm}^{2} / \mathrm{Vsec}$ の超高移動 度と, 極めて低い欠陷密度を持つ4)ゆえ, チャネル内をキャ リアが無散乱走行するバリスティック MOSFET の実現が期 待出来る.しかしながら実際にデバイス構造中にチャネルと して組み込むためには，ゲート絶縁膜を挟んでグラフェンを 半導体基板の上に貼り付ける必要がある. ゆえにデバイス応 用としては，グラフェンそのものの物性だけでなく基板側か らの影響も含めた特性を考慮しなくてはならない。例えば,

$\mathrm{SiO}_{2}$ 中に存在する固定電荷が散乱源となってグラフェンの キャリア移動度を劣化させる要因のひとつになっているとの 指摘がある5).これまで, グラフェンや CNTなどの低次元 材料の伝導特性は, トランジスタ構造を作りこんでそのデバ イス特性から抽出するか, あるいは 4 端子プローブ法など の多端子測定によって評価してきた. しかしマクロなコンタ クト電極をグラフェン上に形成した測定では，下地基板中の 固定電荷などがグラフェンの移動度に与える局所的な影響を 直接評価するのは難しい。そこでSCMを含めた様々な $\mathrm{SPM}$ を用いてグラフェン特性の局所的擾乱について評価し た論文が近年増加しつつある。本稿の後半では，SCM を用 いて $\mathrm{SiO}_{2} / \mathrm{Si}$ 基板上のグラフェンの伝導特性を測定する手法 について述べる.

\section{2. 測定系について}

$\mathrm{SCM}$ では, 先鋭化された導電性プローブと試料の間の相 互作用力を, フィードバック制御によりあらかじめ定めたあ る一定值に保ちつつ, プローブー試料間の微小容量を測定す る. Fig. 2(a) に，われわれの研究におけるSCMのブロッ ク図を示す.プローブー試料間の容量測定には, LC 共振器 から構成される容量センサーを用いる. LC 共振器のストリ ップラインの一部となっている導電性プローブが試料に近づ

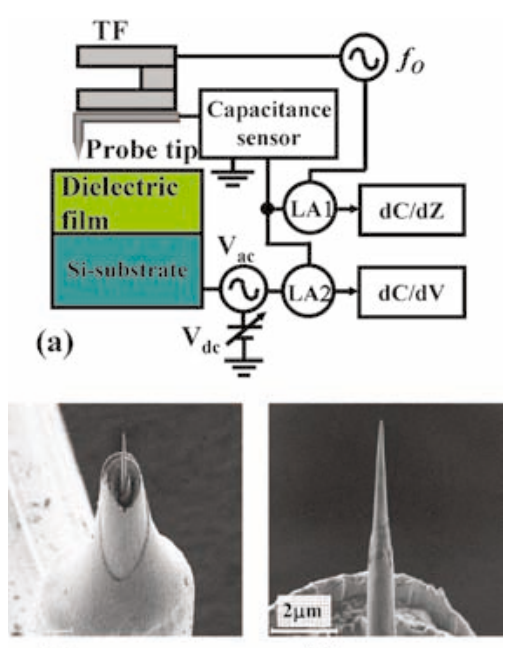

(b)

(c)

Fig. 2 Experimental apparatus and SEM images of SCM probe tip. (a) Schematic setup of SCM. (b) SEM image of typical probe geometry fabricated by FIB milling. (c) SEM image of probe tip apex. ${ }^{17)}$

くと, プローブー試料間の負荷容量によって LC 共振器の出 力が変化するので, この变化分から間接的に微小容量が測定 できる．またプローブ側はグランド電位に落ちているのに対 し, 試料側にはオフセット直流電圧 $\left(\mathrm{V}_{\mathrm{dc}}\right)$ および変調交流 電圧 $\left(\mathrm{V}_{\mathrm{ac}}\right)$ が印加できるようになっている6,7).

$\mathrm{SCM}$ をはじめとする多くの SPM では, 導電性プローブ として $\mathrm{Au}, \mathrm{Pt}$ 等の貴金属を被覆した単結晶 $\mathrm{Si}$ 製のカンチレ バー型プローブを使用している.これに対して本研究では,

Fig. 2(b)，(c)の SEM 像に示すように, 直径数十 $\mu \mathrm{m}$ のタ ングステン線材の先端を FIB で同心円状に先鋭化したもの ${ }^{8)}$ を導電性プローブとして用いている．この加工法によるプ ローブ先端の曲率半径は, $~ 30 \mathrm{~nm}$ 程度である. また, 導電 性プローブ先端と試料間の相互作用力を検出する力センサー として高い機械共振特性を持つ水晶振動子（Tuning Fork; TF）を用いている. TF はプローブ-試料間に働く微弱な力 を, 自身の共振周波数の変化 (Frequency Shift; $\Delta f$ ) とし て感知する ${ }^{9)}$. 本研究の SCM では, $\Delta f$ が一定值を保つよう フィードバック制御をかけながら, 試料表面を走査してい る. また測定は真空 $\left(\sim 10^{-4} \mathrm{~Pa}\right)$ 雾囲気下で行った。この Fig. 2(a)の構成による SCM では, 一度の走査で表面形状像 (Topo), プローブー試料間容量の電圧変調成分像 $(\mathrm{dC} /$ $\mathrm{dV})^{10,11)}$, 及び距離変調像 $(\mathrm{dC} / \mathrm{dZ})^{12,13)}$ が同時に得られる. ここで $\mathrm{dC} / \mathrm{dV}$ 信号, $\mathrm{dC} / \mathrm{dZ}$ 信号は, Fig. 2(a)のブロック図 に示すようにそれぞれ $\mathrm{V}_{\mathrm{ac}}$, 及び $\mathrm{TF}$ の振動によって変調さ れたプローブー試料間容量である．このような構成による SCM の主な利点は,

(1) 導電性プローブを全金属製とすることにより, 被覆金属 層の剥離等による導電性の劣化が無く, またインピーダン スが低いために微小容量信号の感度が向上した.

(2) 水晶振動子の圧電性を利用するために, 従来大半の SPM で必要とされてきたプローブ位置制御用の光学系が 不要となる.よって漏れ光などの影響14,15)を排除して完全 な暗環境下で測定することが可能である. 
の 2 点である. 特に上記(2)については, 光起電力効果に よって半導体試料中のキャリア分布が乱されてしまうので, $p-n$ 接合を含んだデバイス構造や電荷トラップなどを観察す る際には，暗環境下での測定が特に重要な利点となる.

\section{3. 実験結果および考察}

\section{1 誘電体薄膜観察}

Fig. 3 (a) 〜 (c) に，Fig. 2(a)の構成の SCM によって等間 隔に並んだ $p$-MOSFET を断面方向から観察した結果16)を， また Fig. $3(\mathbf{d}) \sim(\mathbf{f}) に p-\mathrm{Si}$ 基板上の極薄 $\mathrm{SiO}_{2}$ （膜厚 1.8 nm）を観察した結果を示す17). Fig. 3(a)の Topo 像では, 表面保護用の層間膜とゲート電極，Si 基板の境界が確認で きる. Fig. 3(b)の dC/dV 像では, ソース/ドレイン端のp$n$ 接合が, $\mathrm{dC} / \mathrm{dV}$ 信号の極性の切り替わる位置として観察 できる。そして Fig. $3(\mathrm{c}) の \mathrm{dC} / \mathrm{dZ}$ 像では, $\mathrm{dC} / \mathrm{dV}$ 像と同 椂に $p-n$ 接合の近傍で信号強度の変化が見られる. 一方,

Fig. 3(d)の Topo 像では, $\mathrm{SiO}_{2}$ 表面のマクロラフネスが確 認できるが，Fig. 3(e)の dC/dV 像では，特に構造らしきも のは観察されない。しかし Fig. 3 (f)の dC / d 像では, Topo 像のマイクロラフネスに対応したコントラストが見ら れる.

この $\mathrm{dC} / \mathrm{dV}$ 像と $\mathrm{dC} / \mathrm{dZ}$ 像の見え方の差は次のように説明 できる. SCMにより測定される微小容量は, 導電性プロー ブ ·表面酸化膜 · $\mathrm{Si}$ 基板による点接触の金属-絶縁体-半導 体（metal-Insulator-semiconductor; MIS）接合の $\mathrm{C}-\mathrm{V}$ 特性 に依存する。従って $\mathrm{dC} / \mathrm{dV}$ 像は, 極薄 $\mathrm{SiO}_{2}$ を挟んでプ ローブ直下の $\mathrm{Si}$ 基板中に形成されるキャリア空乏層を，外 部から印加する交流電界 $\mathrm{V}_{\mathrm{ac}}$ によって变調することにより得 られるため，その空間分解能は $\mathrm{Si}$ 基板中のキャリア濃度に 依存する。ゆえに $p-n$ 接合のようなキャリアの極性や濃度 の変化に対しては $\mathrm{dC} / \mathrm{dV}$ 像は敏感であるが，下地基板中の キャリア濃度が一定ならばほとんど何も見えない。それに対 して, プローブー試料間の静電容量に相当する $\mathrm{dC} / \mathrm{dZ}$ 信号に は，表面酸化膜の容量である $\mathrm{C}_{\mathrm{OX}}$ （電圧に依存しない容量成

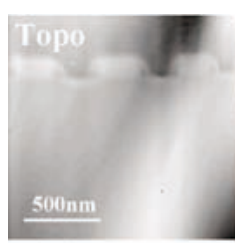

(a)

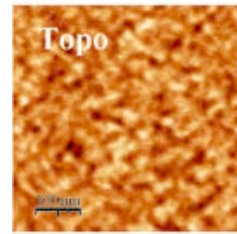

(d)

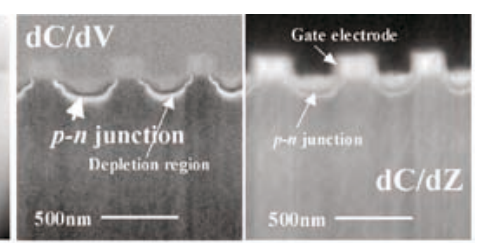

(c)

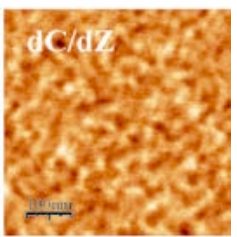

(f)
Fig. 3 Cross-sectional images for periodically arrayed pMOSFET simultaneously obtained by SCM: (a ) Topography, (b) $\mathrm{dC} / \mathrm{dV}$ image, and (c) $\mathrm{dC} / \mathrm{dZ}$ image. And SCM images of ultrathin $\mathrm{SiO}_{2}$ film: (d) topography image, (e) $\mathrm{dC} / \mathrm{dV}$ image, and (f) $\mathrm{dC} / \mathrm{dZ}$ image.
分）と, プローブ直下の半導体基板中に形成されるキャリア 空乏層容量に由来する $\mathrm{C}_{\mathrm{dep}}$ （電圧に依存する容量成分）の両 方が含まれる。下地基板中のキャリア濃度が一定ならば， $\mathrm{dC} / \mathrm{dZ}$ 像は $\mathrm{C}_{\mathrm{OX}}$ の変化を, すなわち表面酸化膜厚の変化を 検出することができると思われる. また, $\mathrm{dC} / \mathrm{d} Z$ 像の分解 能についてはプローブ先端に扔ける電界の集中度, すなわち 導電性プローブの先鋭度と試料表面の誘電率に依存するゆえ に, $\mathrm{dC} / \mathrm{dV}$ 像にくらべてより高分解能が期待できる.

また, $\mathrm{dC} / \mathrm{d} Z$ 像は試料表面の誘電体薄膜だけでなく, $\mathrm{C}_{\mathrm{dep}}$ をと扎てより下層の $\mathrm{Si}$ 基板側の状態も反映する. 以下に その一例として, high- $k$ 膜の SCM 観察例を紹介する18,19). 観察に用いた high- $k$ 試料は, $p-\mathrm{Si}$ 基板上の $\mathrm{SiO}_{2}$ （膜厚 0.5 $\mathrm{nm}$ ）上に, Atomic Layer Deposition（ALD）法により成膜 した窒化 Hf シリケート（HfSiON）膜（膜厚 $2.5 \mathrm{nm）を，}$ さらに成膜後に $1000^{\circ} \mathrm{C}$ で30秒間アニールしたものである.

Fig. $4(\mathbf{a})$ ，(b)はそれぞれプローブー試料間に $\mathrm{V}_{\mathrm{dc}}$ が $0 \mathrm{~V}$ の 条件下で測定した high- $k$ 膜の表面形状（Topo）像と $\mathrm{dC} / \mathrm{d} Z$ 像，また同じく Fig. $4(\mathbf{c})$ ，(d) は下地 $\mathrm{Si}$ 基板内のキャリア が蓄積状態となるように $\mathrm{V}_{\mathrm{dc}}$ を試料側に $+2 \mathrm{~V}$ 印加して同じ 領域を走査したそれぞれ Topo 像と $\mathrm{dC} / \mathrm{d} Z$ 像である. Fig. 4 (a)の Topo 像では, HfSiON 膜表面のマイクロラフネスが 見られるのみであるが，一方，Fig. 4(b)の dC/dZ 像では， 明らかに Topo 像には見られないコントラストである暗スポ ット（A，B，Cの点線で囲った領域）が観察されている。 たさらに，Fig. 4(a) と，蓄積条件下で走査した Fig. 4(c)の Topo 像ではあまり差は見られないが，蓄積条件下で走査し た Fig. 4(d)の dC/dZ 像では A, B , C の暗スポットが消失し ている.

これら電圧印加条件による SCM 測定像の変化は, Fig. 5 に示すラインプロファイル同士を比較することによってより 明らかとなる. Fig. 4(b) 中の暗スポットAの外縁部を横切 る L-L'に抢けるラインプロファイル (Fig. 5(a)) では, 電 圧条件に対してTopo 像のプロファイルは変化しないが, $\mathrm{dC} / \mathrm{dZ}$ 像のプロファイルでは, Fig. 4(b)の暗スポットAに 相当する凹部が蓄積条件下では消失している. 一方, M-
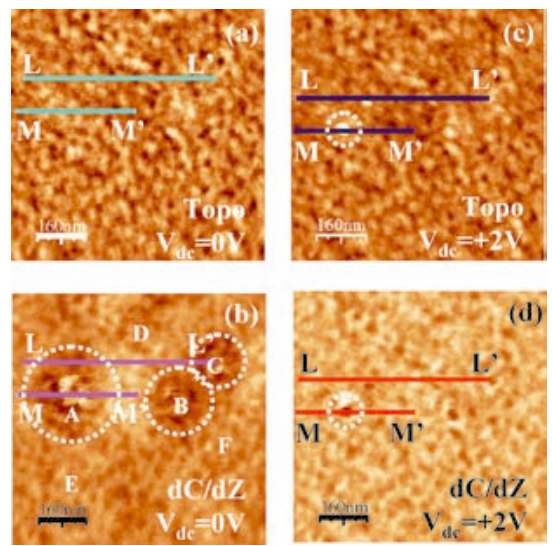

Fig. 4 Topography and corresponding $\mathrm{dC} / \mathrm{dZ}$ images of Hf$\mathrm{SiON} / \mathrm{SiO}_{2}$ dielectrics. (a) topography under $\mathrm{V}_{\mathrm{dc}}=0 \mathrm{~V}$, (b) $\mathrm{dC} / \mathrm{dZ}$ under $\mathrm{V}_{\mathrm{dc}}=0 \mathrm{~V}$, (c) topography under $\mathrm{V}_{\mathrm{dc}}=+2 \mathrm{~V}$, (d) $\mathrm{dC} / \mathrm{dZ}$ under $\mathrm{V}_{\mathrm{dc}}=+2 \mathrm{~V}$. The pairs of (a) - (b) and (c) (d) were consecutively scanned on the same region. 

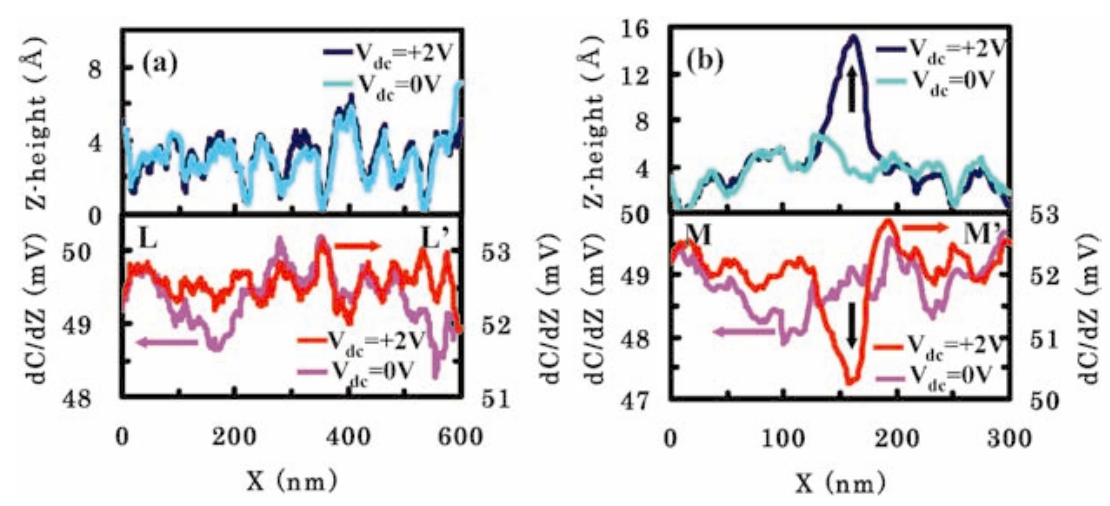

Fig. 5 Cross-sectional profiles along the lines indicated in Figs. 4. (a) profiles along the line L-L'. Top pair represents the topography profiles (blue: $\mathrm{V}_{\mathrm{dc}}=+2 \mathrm{~V}$, light blue: $\mathrm{V}_{\mathrm{dc}}=0 \mathrm{~V}$ ), and bottom pair shows the $\mathrm{dC} / \mathrm{dZ}$ profiles $\left(\right.$ red: $\mathrm{V}_{\mathrm{dc}}=+2 \mathrm{~V}$, pink: $\left.\mathrm{V}_{\mathrm{dc}}=0 \mathrm{~V}\right)$. (b) profiles along the line $\mathrm{M}-\mathrm{M}^{\prime}$. Top pair represents the topography profiles (blue: $\mathrm{V}_{\mathrm{dc}}=+2 \mathrm{~V}$, light blue: $\mathrm{V}_{\mathrm{dc}}=0 \mathrm{~V}$ ), and bottom pair shows the $\mathrm{dC} / \mathrm{dZ}$ profiles (red: $\mathrm{V}_{\mathrm{dc}}=+2 \mathrm{~V}$, pink: $\mathrm{V}_{\mathrm{dc}}=0 \mathrm{~V}$ ). ${ }^{18)}$

M'におけるラインプロファイル（Fig. 5(b)) においては, 矢印で示すように蓄積条件下では Topo 像のほうで暗スポッ ト Aの中心に相当する位置に高さ $1 \mathrm{~nm}$ 程度のシャープな凸 部が生ずる.

局所 $\mathrm{C}-\mathrm{V}$ 測定により，より詳細に膜中電荷分布に関する 知見が得られる。プローブの位置を固定して， $\mathrm{V}_{\mathrm{dc}}$ を掃印し ながら $\mathrm{dC} / \mathrm{dZ}$ 信号の変化を測定した結果 $(\mathrm{dC} / \mathrm{d} Z-\mathrm{V}$ カーブ) をFig. $6(\mathbf{a})$ に示す。暗スポット $\mathrm{A}, \mathrm{B}, \mathrm{C} て ゙ の \mathrm{dC} / \mathrm{dZ}-\mathrm{V}$ カーブは, その他の場所 $(\mathrm{D}, \mathrm{E}, \mathrm{F})$ での $\mathrm{dC} / \mathrm{dZ}-\mathrm{V}$ カーブ に比べてその電圧依存性の傾きは大きい。 また，暗スポット の中心部で測定された $\mathrm{dC} / \mathrm{d} Z-\mathrm{V}$ カーブでは, 矢印で示すよ うに不連続な “飛び”が見られる。この不連続点は, Fig. 6 (b)に示すように, 電圧掃印方向に対してヒステリシスを持 つが，一方暗スポット以外で測定した $\mathrm{dC} / \mathrm{d} Z-\mathrm{V}$ カーブに は，そのような変化は見られない，

これらの結果をまとめると, 試料中の電荷分布は Fig. 7 のように説明できる. まず, 蓄積条件下では $\mathrm{dC} / \mathrm{dZ}$ 像の暗 スポットが消失することから，これらの暗スポットは $\mathrm{C}_{\mathrm{dep}}$ の不均一な空間的広がりに由来することがわかる。すなわ ち, 暗スポットでは, high- $k$ 膜である HfSiON 膜中に正の 固定電荷が凝集して分布しているために，局所的に下地 $\mathrm{Si}$ 基板側が空乏化していると考えられる。 また, $\mathrm{dC} / \mathrm{d} Z-\mathrm{V}$ カーブの電圧依存性の差から, 暗スポットでは HfSiON 膜 の下地膜である $\mathrm{SiO}_{2}$ と $\mathrm{Si}$ 基板の間に界面電荷が存在すると 考えられる.さらに, 暗スポット中心部では $\mathrm{HfSiON}$ 膜表 面近傍の非常に浅い領域に電子トラップが存在していること がわかる。これは複数の結果から確認出来る。まず，Fig. 6 (a)に示した暗スポットの中心部 $(\mathrm{A}, \mathrm{B}, \mathrm{C})$ に扔ける $\mathrm{dC} /$ $\mathrm{dZ}-\mathrm{V}$ カーブの不連続点は, $\mathrm{V}_{\mathrm{dc}}$ の増大に伴い $\mathrm{dC} / \mathrm{dZ}$ 信号が 増える方向に変化している，また，Fig. 6(b)に見るように この不連続点はヒステリシスを持つことから, 可逆過程であ ることがわかる，よって，SCM の導電性プローブと Hf$\mathrm{SiON}$ 膜中の電荷トラップの間で電子が行き来した結果, 下 地 $\mathrm{Si}$ 基板の $\mathrm{C}_{\mathrm{dep}}$ が変化してこのような $\mathrm{dC} / \mathrm{dZ}-\mathrm{V}$ カーブの 不連続点として観察されたと説明できる。ささらに, Fig. 5 (b)に示したように, $\mathrm{V}_{\mathrm{dc}}$ を試料側に $+2 \mathrm{~V}$ 印加した蓄積条
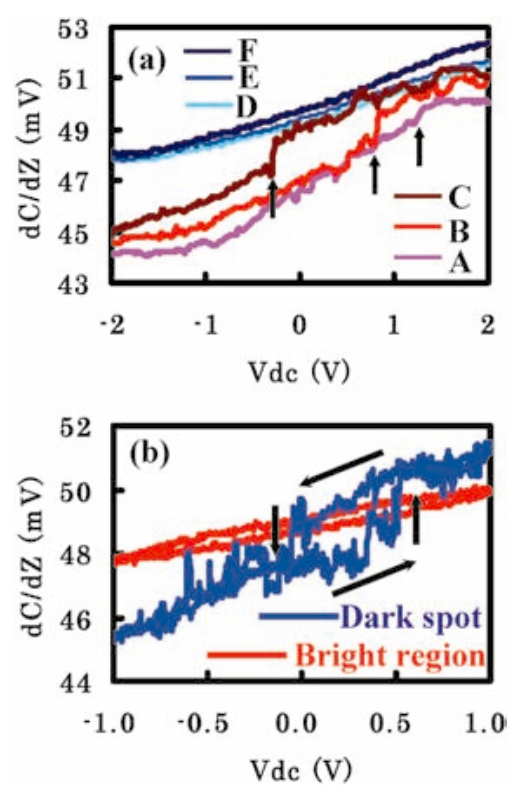

Fig. 6 Spatially resolved $\mathrm{dC} / \mathrm{dZ}-\mathrm{V}$ spectra. (a) $\mathrm{dC} / \mathrm{dZ}-\mathrm{V}$ spectra scanned at center of dark-spots labeled A (pink), B (red), and $\mathrm{C}$ (brown), and relative bright-contrasted region of $\mathrm{D}$ (light blue), $\mathrm{E}$ (blue), and $\mathrm{F}$ (deep blue), as indicated in Fig. 4 (b). (b) $\mathrm{dC} / \mathrm{dZ}-\mathrm{V}$ spectra scanned at dark-spot region (blue) and at bright-contrasted region (red).18)

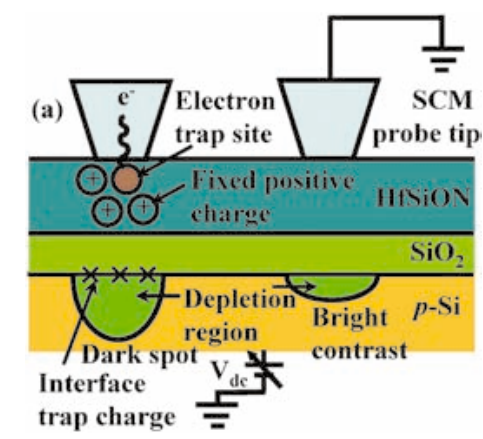

Fig. 7 Schematic illustration of charged defects within high- $k$ dielectrics. At dark-spot region, positive fixed charges and electron trap sites are distributed within $\mathrm{HfSiON}$, and interface trap charges also exist between $\mathrm{SiO}_{2}$ underlayer and $\mathrm{Si}$ substrate. ${ }^{18)}$ 
件下の測定では, Topo 像で暗スポットの中心部のみが選択 的に凸となっている. さきにも述べたように，導電性プロー ブと試料の間の相互作用力は, 水晶振動子の共振周波数の変 化として感知され，フィードバック制御によって一定值に保 たれている.ここで, プローブー試料間の相互作用力 $F_{\text {all }}$ は, プローブが $\mathrm{HfSiON}$ 膜表面から受ける抗力 $\left(F_{\text {repulsive }}\right)$ と, HfSiON 膜中の固定正電荷による静電引力 $\left(-F_{\text {attractive }}\right)$ の和 $\left(F_{\text {repulsive }}-F_{\text {attractive }}\right)$ となる. プローブから $\mathrm{HfSiON}$ 膜 中の電荷トラップヘ電子が注入されると, $F_{\text {attractive }}$ が減少す るのでその分 $F_{\text {all }}$ がわずかに増える. すると $F_{\text {all }}$ を一定に保 つようフィードバック制御によってプローブー試料間のギャ ップは広がるので, 電子の注入ポイントは Topo 像で凸に見 えるというわけである。

さらに, 電子の注入量とトラップ位置を見積もることも可 能である ${ }^{20,21)}$. まず, 水晶振動子のバネ定数と共振周波数変 化による力学解析から， $F_{\text {all }}$ の変化量は

$$
\Delta F_{\text {all }}=2 k \Delta f / f_{\mathrm{O}},
$$

として見積もることが出来る.ここで， $k$ は水晶振動子の バネ定数 $(8000 \mathrm{~N} / \mathrm{m}), f_{\mathrm{O}}$ は水晶振動子の共振周波数 (31 $\mathrm{kHz}), \Delta f$ は水晶振動子の共振周波数变化 $(100 \mathrm{mHz} / \mathrm{nm})$ であり, $\Delta F_{\text {all }}=\sim 5.2 \times 10^{-2} \mathrm{~N} / \mathrm{m}$ という值が得られる。一 方, 電子の注入による $F_{\text {attractive }}$ の減少分は, 静電場解析によ っ

$$
\begin{aligned}
& \begin{aligned}
\Delta F_{\text {attractive }}= & \frac{q^{2} r}{4 \pi \varepsilon_{O} \varepsilon_{e f f}^{2}} \times \frac{3 z^{2}+r^{2}-l^{2}}{\left(z^{2}+l^{2}-r^{2}\right)^{3}}-\frac{q V_{b} r}{\varepsilon_{e f f}} \\
& \times \frac{l^{2}-2 z^{2}}{\left(z^{2}+l^{2}\right)^{2.5}},
\end{aligned} \\
& z=r+a+d, \\
& \varepsilon_{\text {eff }}=\left(\varepsilon_{o x}+1\right) / 2,
\end{aligned}
$$

として見積もることが出来る.ここで, $q$ は注入電荷量, $d$ は HfSiON 膜表面から電荷トラップまでの深さ, $l$ は電荷卜 ラップとプローブ先端までの横方向の距離（プローブがトラ ップの直上に来たときに電荷移動が起こると考えられるので $l=0), r$ は導電性プローブの先端半径 $(30 \mathrm{~nm}), \varepsilon_{o}$ は真空 誘電率, $\varepsilon_{o x}$ は $\mathrm{HfSiON}$ の比誘電率 $(10 \sim 15), V_{b}$ は印加電 圧, $a$ は電荷移動が起こる際のプローブから $\mathrm{HfSiON}$ 膜表面 までの最短縦方向距離（0）である. q を- $1 \mathrm{e}, \mathrm{d}=4 \AA$ とお いた場合， $\Delta F_{\text {attractive は〜 }} .0 \times 10^{-2} \mathrm{~N} / \mathrm{m}$ となり，先に見積 もった $\Delta F_{\text {all }}$ とほぼ等しい值が得られる.すなわち, 暗スポ ットの中心部では, 表面から $4 \AA$ 程度の極めて浅い領域に 電子トラップが存在し, 導電性プローブからトラップヘ 1 個の電子が注入された結果, 下地 $\mathrm{Si}$ 基板の $\mathrm{C}_{\mathrm{dep}}$ がわずかに 変化して Fig. 6 に示すような $\mathrm{dC} / \mathrm{d} Z-\mathrm{V}$ カーブの不連続点と して観察された，と解釈できる.

ここで紹介したような SCM による局所 $\mathrm{C}-\mathrm{V}$ 測定は， high- $k$ 膜以外の他の材料系の評価にも応用されており, 例 えば単一 InAs 量子ドット ${ }^{22)} \mathrm{ee}$ 量子ドットのエネルギー 準位について議論した論文 ${ }^{23)}$, さらには極低温䨌囲気 SCM によって単一ドナードーパント原子のエネルギー準位を測定 した論文 ${ }^{24)}$ なども報告されており，離散的なエネルギー準 位を評価する有力な評価手法となっている.

一方別の応用として, プローブ側から電荷注入すること

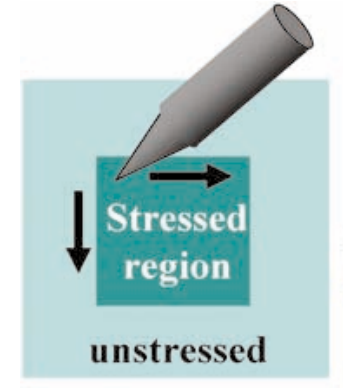

(a)

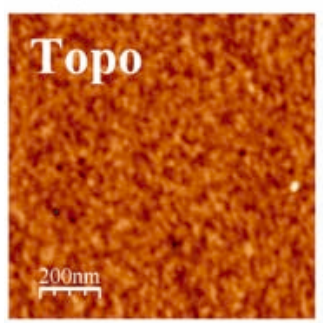

(c)

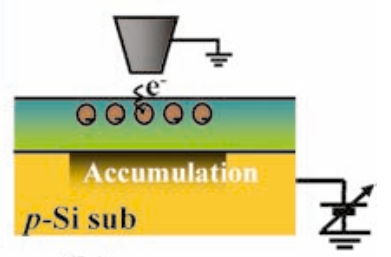

(b)

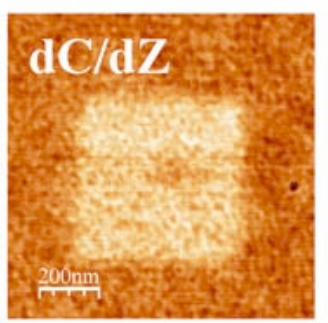

(d)
Fig. 8 (a) Schematic illustration of bias-stress experiments. (b) Schematic view of charge injection from SCM probe to the high- $k$ film. (c) Topography image, and (d) corresponding $\mathrm{dC} / \mathrm{dZ}$ image of high- $k$ film after charge injection. ${ }^{25}$

で, 誘電体膜中に分布する電荷トラップへの『書き込み』を 行なうことも出来る. Fig. 8 は, $\mathrm{TiO}_{2} / \mathrm{HfSiO} / \mathrm{SiO}_{2}$ という 3 層構造の積層型 high- $k$ 膜について, SCM によって電荷注 入実験をおこなった結果である ${ }^{25)}$. 実験では, Fig. 8(a)の 模式図に示すように，まず試料表面の走査領域の中心部に, 一定值の $\mathrm{V}_{\mathrm{dc}}$ 印加でストレスをかけ，その後 $0 \mathrm{~V}$ に戻してス トレス未印加領域を含めた全体を走査する.この場合, Fig. 8(b) に模式的に示すように, 積層 high- $k$ 膜中に分布する電 荷トラップに SCM プローブから電子が注入された結果, 基 板である $p-\mathrm{Si}$ がストレス印加領域において局所的に蓄積状 態となる.そのような測定を行なった結果を, Fig. 8(c) お よび(d)に示す. Fig. 8(c)の Topo 像では high- $k$ 膜表面にほ とんど何の変化も見られないが，一方対応する Fig. 8(d)の $\mathrm{dC} / \mathrm{d} Z$ 像では, 中央のストレス印加領域が明コントラスト として, すなわち局所蓄積の結果周囲のストレス未印加領域 にくらべてプローブー試料間容量がより大きく観察されてい る. 我々は積層型 high- $k$ 膜のプロセス条件に対応してこの ような測定を行なうことにより, 電荷トラップ分布のアニー ル温度依存性について検討した。 またこのような測定はもっ とも初期の SCM 実験において Si 酸窒化膜に対してメモリ 応用を意識して行なわれており ${ }^{26)}$, 近年でも SCM の発展形 である走査型非線形誘電率顕微鏡 (Scanning Nonlinear dielectric Microscopy; SNDM）を用いて強誘電体薄膜に対して 行なうことにより, 超高密度記録ストレージデバイスへの応 用を探索した例がある ${ }^{27)}$.

以上紹介したように，SCM によるミクロな観察では，半 導体基板上の誘電体薄膜中に存在する電荷分布を評価できる ようになっており, 成膜プロセスの最適化やデバイス特性へ の影響を考察する有力な手掛かりになると期待される．また 今後の発展としては解析手法の充実と分解能の向上が見込ま 
れる. 前者については例えば誘電体薄膜の膜厚や誘電率の絶 対值の見積もりに関する手法が近年多くの論文で議論されて いる28-31). さらにその応用として, プローブー試料間容量測 定によってフォースカーブを更正する手法も提案されてい る ${ }^{32)}$. また後者については, SNDMにおいて一部の試料の 観察で原子. 分子分解能まで得られており ${ }^{33-35)}$, 空間分解 能の展望について心強い結果を示している.

\section{2 伝導性薄膜観察}

前節では，SCM を用いた誘電体薄膜評価について解説し た. 一方, 新たな応用として, 半導体ナノワイヤなど低次元 材料の伝導特性を SCM やそのバリエーションにより評価す る試みについていくつかの提案がなされている36-38). 本節 では, $\mathrm{SiO}_{2} / \mathrm{Si}$ 基板上のグラフェンを $\mathrm{SCM}$ 測定した結果 と，その解釈について述べる.

Fig. 9 (a) に, SCM によるグラフェン観察の実験配置図を 示す. SCM 自体は Fig. 2(a)に示したものと同一の測定系で ある. バルクグラファイトからへき開法によって分離された グラフェンは, 低抵抗 $\mathrm{Si}$ 基板上の十分な厚み（膜厚 $300 \mathrm{~nm}$ ) を持つ $\mathrm{SiO}_{2}$ 膜上に配置されており, ゆえにバックゲートで ある $\mathrm{Si}$ 基板からグラフェンは $\mathrm{SiO}_{2}$ 膜によって電気的に分離 されている. Fig. 9 (b), (c)に, グラフェンの SCM 測定結 果を示す. Fig. 9(b)に示す Topo 像では, ちょうど画像の 中央部に縦方向に走る一段のステップが見える. そのステッ プの左側 (Region-I) と右側の領域（Region-II）では，と もにその表面には㱀状のマイクロラフネスが観察される．こ こで, Region-I は 2 層グラフェン(Bilayer Graphne: BLG), Region-II は多層グラフェン (Few-layer Graphene: FLG) である. 一方, Figs. 9 (c)の dC / dZ 像では, 明瞭な 2 段階 のコントラストが見られる. Fig. $9(\mathbf{d})$ に示すラインプロフ アイル L-L'では, Topo 像のステップと $\mathrm{dC} / \mathrm{dZ}$ 像のコント ラストの対応がはっきり判る. Topo 像の断面プロファイル から，Region-I に対して Region-II が抢よそ〜2 nm 程度高 いことがわかる．これは単層グラフェンの膜厚が $4 \sim 5 \AA$ で あることを考慮すると, Region-II の FLG では 6〜 7 層程度 のグラフェンが積層していると考えられる. 一方, $\mathrm{dC} / \mathrm{d} Z$ 像のラインプロファイルでは, Region-II 側が Region-I 側 よりも明コントラスト，すなわちプローブー試料間容量は FLG 側が BLG 側より大である，という結果を示している.

Fig. 9 (b)，(c)に示すグラフェンの SCM 測定の結果は, 何を意味しているのであろうか？ 詳細な考察は未だ整理し きれていないが，最近報告された SCM を用いた単層グラフ エンの移動度測定に関する論文 ${ }^{39-41)}$ を元にすると，少々荒 っぽいが以下のような解釈が考えられる. まず，2. でも述 ベたように, SCM では導電性プローブが LC 共振器から構 成される容量センサーの一部となっている.この LC 共振器 は, $\sim 1 \mathrm{GHz}$ 程度の高周波 (Ultra-high Frequency: UHF) で発振して抢り，ゆえに導電性プローブを通じて試料側に UHF 電界が伝播されている. Fig. 10 にグラフェン試料表 面に㧍けるUHF 電界の広がりを模式的に示す。ここで, 導 電性プローブから伝播した UHF 電界は, グラフェン中にキ ャリアを誘起し，プローブの直下にある広がりを持ったキャ リア分布（Fig. 10中に $S_{\text {eff }}$ と記した影のついた領域）を形成

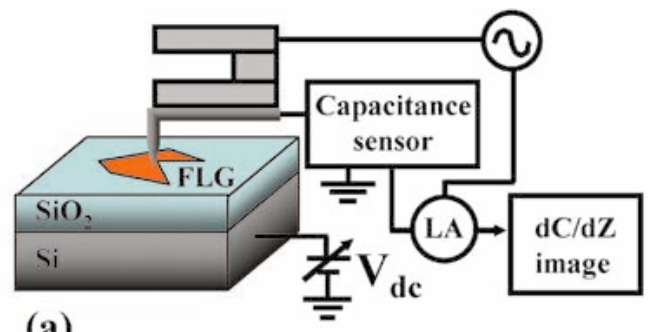

(a)
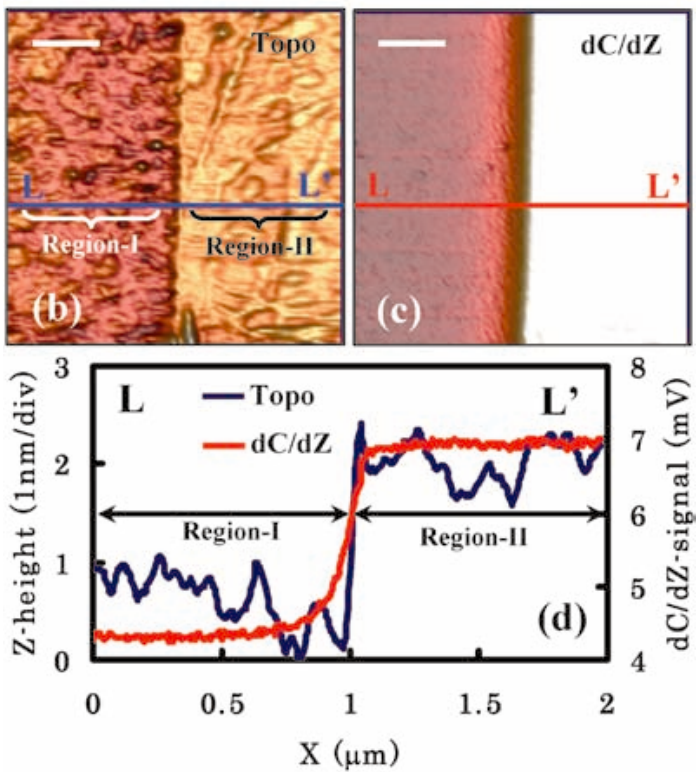

Fig. 9 (a) Structure of graphene sample on $\mathrm{SiO}_{2} / \mathrm{Si}$ substrate and schematic diagram of our SCM measurement. (b) Topographic image, and (c) corresponding $\mathrm{dC} / \mathrm{dZ}$ image of $\mathrm{FLG}$ sheet. The imaging area was $2 \times 2 \mu \mathrm{m}^{2}$, and the scale bars in (d) and (e) are $400 \mathrm{~nm}$. (d) Cross-sectional profiles of topography (blue) and $\mathrm{dC} / \mathrm{dZ}$ (red) along $\mathrm{L}-\mathrm{L}^{\prime}$ in (b) (c).

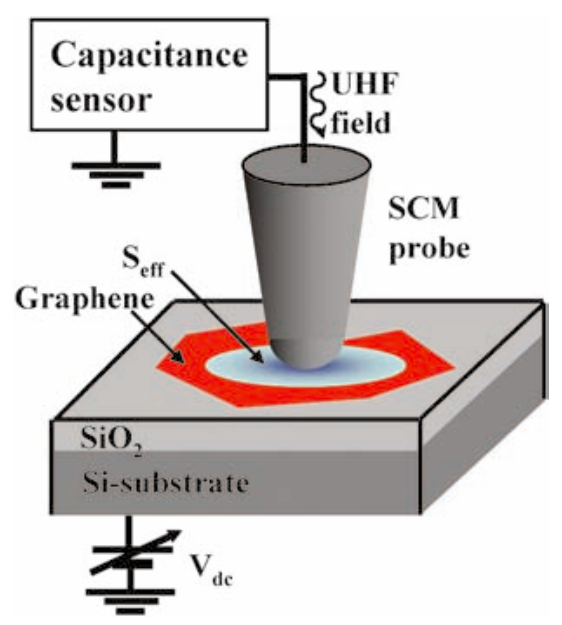

Fig. 10 Schematic illustration of SCM probe tip on graphene sample, depicting the induced carrier distribution as $S_{\text {eff. }}$.

する．この $S_{\text {eff }}$ は, 非定常状態にあるキャリア分布であり， その広がりは次のように表わされる。

$S_{\text {eff }}=\pi \times L_{d}^{2}(\mathrm{Ld} ;$ グラフェン中におけるキャリアの 平均自由行程長),

すなわち，この $S_{\text {eff }}$ を測定できれば，グラフェン中の平均自 
由行程長を見積もることが可能となる. またさらに平均自由 行程長からフェルミ波長やキャリア移動度などの伝導特性に 関わる物理量を求めることも可能である.

一方，この $S_{\text {eff }}$ は容量測定から見積もることができる. 導 電性プローブ/グラフェン $/ \mathrm{SiO}_{2} / \mathrm{Si}$ 基板全体の容量 (Call) は，次のように近似的に表わすことが出来る.

$$
C_{\text {all }}=\frac{\varepsilon_{o} \varepsilon_{\mathrm{SiO}_{2}} S_{e f f}}{d}
$$

(d ; 下地 $\mathrm{SiO}_{2}$ 膜厚, $\varepsilon_{o}$; 真空誘電率, $\varepsilon_{\mathrm{SiO}_{2}} ; \mathrm{SiO}_{2}$ の 比誘電率),

つまり, Fig. 9 (c)の dC $/ \mathrm{dZ}$ 像は, FLG 側の $C_{\text {all }}$ は BLG 側 のCallよりも大きいという結果を示している.これは上述 の $S_{\text {eff }}$ の差, つまり FLG と BLGの平均自由行程長による広 がりの違いを反映していると思われる．たしかにFLGと BLGの移動度の違いを考えると, もっともらしい解釈であ る.

ただし実際の系はもう少し複雑で, 導電性プローブは TF によって試料面に対して垂直方向に振動しているために, プ ローブー試料間の空隙の影響や，またグラフェン自身が持つ 容量 (Quantum capacitance $)^{42)}$ の影響も考慮しなくてはな らない. 実験による $C_{\text {all }}$ の抽出と, その定量解析が今後の最 大の課題であるが, 理論計算や 3 次元電界シミュレーショ ンとの併用により解決できると考える.

従来, グラフェンや CNT, ナノワイヤなどの導電性低次 元材料の電気特性の評価は, 電流測定 AFM (ConductiveAFM: C-AFM）やSTMによって行なわれてきた。C$\mathrm{AFM}, \mathrm{STM}$ ともに測定に際してはコンタクト電極を試料上 に形成する必要が有るが，CNTやグラフェン上に良好な オーミック特性を持つコンタクト電極を形成することは難し く，測定上の大きな制約となっている．またコンタクト電極 形成時のダメージやレジスト残渣などの表面污染などの外因 的な影響によって，材料本来の物性が見え難くなるという問 題も指摘されている43). これらに対してここで紹介した SCM による測定は, Fig. 9(a)に示すように試料上にコンタ クト電極を形成する必要は無いので, 従来手法に比べて測定 上の制約は少ない，という長所が挙げられる. またグラフェ ンではキャリア密度やキャリア極性は印加電圧によって大き く変化するが, 導電性プローブ側から DC オフセット電圧を 印加して $S_{\text {eff }}$ を測定すれば，移動度のキャリア密度・極性へ の依存性も比較的簡単に評価できると思われる. 実験の蓄積 による今後の発展が望まれる。

\section{4. まとめ}

先鋭化した金属線材を導電性プローブとしたSCMによ る, 誘電体薄膜測定手法について解説した. Topo 像, $\mathrm{dC} /$ $\mathrm{d} Z$ 像，および局所 $\mathrm{C}-\mathrm{V}$ 測定を組み合わせることにより，誘 電体膜中の電荷分布を評価できることを示した．またグラフ ェンの伝導特性を SCM により評価する試みについて述べ た。本稿で報告した応用以外にも，例えば $\mathrm{GaN}^{44)}$ や $\mathrm{ZnO}^{45)}$ など非 Si 系半導体材料へのキャリアドーピング評価や，さ らにはFig. 2(a)に示したものとほぼ同様の測定系を, 極低 温䨌囲気・強磁場中に導入して量子ホール系のエッジ状態を
測定しようという試みも報告されている ${ }^{46,47)}$.このような $\mathrm{SCM}$ をはじめとする顕微分光技術をもとにした基礎材料物 性の精密な議論が，新世代のエレクトロニクス技術の基盤と なると信ずる。

\section{謝辞}

本稿で紹介致しました研究の一部は，筆者（内藤）が NECシリコンシステム研究所に在職中に行ないました．有 意義な御助言と議論を頂きました，元 NECシリコンシステ 么研究所の大久保紀雄博士に深謝致します.

\section{〔文献〕}

1) M. Nishizawa, L. Bolotov and T. Kanayama: Appl. Phys. Lett., 90 (2007) 122118.

2) L. Zhang, K. Ohuchi, K. Adachi, K. Ishimaru, M. Takayanagi and A. Nishiyama: Appl. Phys. Lett., 90 (2007) 192103.

3) http://www.intel.co.jp/jp/intel/pr/press2007/070129.htm

4) E. H. Hwang, S. Adam and S. Das Sarma: Phys. Rev. Lett., 98 (2007) 186806.

5) K. Nagashio, T. Nishimura, K. Kita and A. Toriumi: Appl. Phys. Express, 2 (2009) 025003.

6) Y. Naitou and N. Ookubo: Appl. Phys. Lett., 85 (2004) 2131.

7) Y. Naitou, A. Ando, H. Ogiso, S. Kamiyama, Y. Nara, K. Nakamura, H. Watanabe and K. Yasutake: Appl. Phys. Lett., 87 (2005) 252908.

8) K. Akiyama, T. Eguchi, T. An, Y. Fujikawa, Y. YamadaTakamura, T. Sakurai and Y. Hasegawa: Rev. Sci. Instrum., 76 (2005) 033705.

9) F. J. Giessibl: Appl. Phys. Lett., 76 (2000) 1470.

10) L. Vines, E. Monakhov, B. G. Svensson, J. Jensen, A. Hallén and A. Y. Kuznetsov: Phys. Rev. B, 73 (2006) 085312.

11) K. M. Wong, W. K. Chim, K. W. Ang and Y. C. Yeo: Appl. Phys. Lett., 90 (2007) 153507.

12) J. J. Kopanski and S. Mayo: Appl. Phys. Lett., 72 (1998) 2469.

13) K. Goto and K. Hane: J. Appl. Phys., 84 (1998) 4043.

14) C. C. Leu, C. H. Chien, C. Y. Chen, M. N. Chang, F. Y. Hsu, C. T. Hu and Y. F. Chen: Appl. Phys. Lett., 86 (2005) 092906.

15) J. Smoliner and W. Brezna: Rev. Sci. Instrum., 78 (2007) 106104.

16) Y. Naitou and N. Ookubo: Jpn. J. Appl. Phys., 43 (2004) 1848.

17) Y. Naitou, A. Ando, H. Ogiso, S. Kamohara, F. Yano and A. Nishida: Jpn. J. Appl. Phys., 47 (2008) 1056.

18) Y. Naitou, A. Ando, H. Ogiso, S. Kamiyama, Y. Nara, K. Yasutake and H. Watanabe: J. Appl. Phys., 101 (2007) 083704.

19) 内藤裕一, 安藤 淳, 小木兽久人, 神山 聡, 奈良安雄, 安 武 潔, 渡部平司：顕微鏡 43 (2008) 287.

20) R. Ludeke and E. Cartier: Appl. Phys. Lett., 78 (2001) 3998.

21) J. M. Sturm, A. I. Zinine, H. Wormeester, B, Poelsema, R. G. Bankras, J. Holleman and J. Schmitz: J. Appl. Phys., 97 (2005) 063709.

22) J. Smoliner, W. Brezna, P. Klang, A. M. Andrews, and G. Strasser: Appl. Phys. Lett., 92 (2008) 092112.

23) K. M. Wong: Jpn. J. Appl. Phys., 48 (2009) 085002.

24) I. Kuljanishvili, C. Kayis, J. F. Harrison, C. Piermarocchi, T. A. Kaplan, S. H. Tessmer, L. N. Pfeiffer and K. W. West: Nature Phys., 4 (2008) 227.

25) Y. Naitou, H. Arimura, N. Kitano, S. Horie, T. Minami, M. Kosuda, H. Ogiso, T. Hosoi, T. Shimura and H. Watanabe: Appl. Phys. Lett., 92 (2008) 012112.

26) R. C. Barrett and C. F. Quate: J. Appl. Phys., 70 (1991) 2725.

27) Y. Cho, K. Fujimoto, Y. Hiranaga, Y. Wagatsuma, A. Onoe, K. Terabe and K. Kitamura: Appl. Phys. Lett., 81 (2002) 4401.

28) G. Gomila, J. Toset and L. Fumagalli: J. Appl. Phys., 104 (2008) 024315. 
29) K. Lai, W. Kundhikanjana, M. A. Kelly and Z. X. Shen: Appl. Phys. Lett., 93 (2008) 123105.

30) A. Guadarrama-Santana and A. García-Valenzuela: Rev. Sci. Instrum., 80 (2009) 106101.

31) Y. Naitou, A. Yasaka and N. Ookubo: J. Appl. Phys., 105 (2009) 044311.

32) Y. Naitou, H. Ogiso and N. Ookubo: Appl. Phys. Lett., 94 (2009) 083104.

33) Y. Cho and R. Hirose: Phys. Rev. Lett., 99 (2007) 186101.

34) S. Kobayashi and Y. Cho: J. Vac. Sci. Technol. B, 28 (2010) C4D18.

35) N. Kin and Y. Cho: J. Appl. Phys., 107 (2010) 104121.

36) J. J. M. Law, S. A. Dayeh, D. Wang and E. T. Yu: J. Appl. Phys., 105 (2009) 014306.

37) M. Bockrath, N. Markovic, A. Shepard and M. Tinkham, L. Gurevich and L. P. Kouwenhoven, M. W. Wu and L. L. Sohn: Nano Lett., 2 (2002) 187.

38) K. Lai, H. Peng, W. Kundhikanjana, D. T. Schoen, C. Xie, S. Meister, Y. Cui, M. A. Kelly and Z. X. Shen: Nano Lett., 9 (2009)
1265.

39) F. Giannazzo, S. Sonde, V. Raineri and E. Rimini: Nano Lett., 9 (2009) 23.

40) S. Sonde, F. Giannazzo, V. Raineri and E. Rimini: J. Vac. Sci. Technol. B, 27 (2009) 868.

41) F. Giannazzo, S. Sonde, V. Raineri and E. Rimini: Appl. Phys. Lett., 95 (2009) 263109.

42) J. Xia, F. Chen, J. Li and N. Tao: Nat. Nanotechnol., 4 (2009) 505.

43) M. Ishigami, J. H. Chen, W. G. Cullen, M. S. Fuhrer and E. D. Williams: Nano Lett., 7 (2007) 1643.

44) J. Sumner, R. A. Oliver, M. J. Kappers and C. J. Humphreys: J. Appl. Phys., 106 (2009) 104503.

45) B. Wang, J. Min, Y. Zhao, W. Sang and C. Wang: Appl. Phys. Lett., 94 (2009) 192101.

46) A. Baumgartner, M. E. Suddards and C. J. Mellor: Rev. Sci. Instrum., 80 (2009) 013704.

47) M. E. Suddards, A. Baumgartner, C. J. Mellor and M. Henini: Physica E, 40 (2008) 1548. 